\title{
Dietary modulation of some digestive enzymes and Metabolic processes in developing marine fish: Applications to diet formulation
}

\author{
J.L. Zambonino Infante ${ }^{a, *}$ and C.L. Cahu ${ }^{a}$ \\ ${ }^{a}$ Nutrition, Aquaculture and Genomics of fish, UMR 1067, IFREMER, BP 70, 29280 Plouzané, France \\ *: Corresponding author : ilzambon@ifremer.fr
}

\begin{abstract}
:
During these last 20 years, many studies have focussed on the development of the digestive tract in marine fish larvae. Most of the studies aimed at acquiring knowledge on the optimal form of dietary supply for different nutrients, in order to formulate a compound diet able to totally replace live preys in the fish larvae feeding sequence. Consequently, most of the studies aimed at describing the effect of dietary adaptation on digestive enzymes profile, the morphology of the main organs, while others aspects of the physiology of the larvae digestive tract (gut hormones, intestinal transport...) were poorly investigated.
\end{abstract}

This review reports the more recent data on dietary modulation of digestive enzymes with a particular emphasis, when possible, on the molecular and hormonal mechanisms controlling enzyme expression in larvae. We examined how the dietary modulation of pancreatic and intestinal enzymes involved in protein digestion can provide useful information concerning the nature and molecular form of a dietary protein supply that would be adequate for larval stages. In the same way, data on lipase and phospholipase A2 paralleled with recent findings on lipid transport, strongly suggests that fish larvae handle phospholipids better than triglycerides.

A new field of research has been opened in fish larvae nutrition, with the study of the effects of some nutrients on the functioning of some metabolic pathways involved in development and their impact on larvae physiology and morphogenesis, as well as the further development of juveniles. These studies revealed cross-talks between some metabolic processes, particularly those concerning vitamin $A$ and polyunsaturated fatty acids, during fish larvae development and unveil the necessity to design a global approach for determining the requirements of some nutrients

Keywords: Fish larvae; Dietary proteins and lipids; Vitamins; Fatty acids; Digestive enzymes; Nuclear receptors 


\section{Introduction}

The morphology and some metabolic pathways in fish larvae are different from those of juvenile or adult fish. These differences lessen throughout the larval period with the maturation of some tissues and organs, in particular with the onset, decrease or increase in activity of a wide range of digestive enzymes (Zambonino Infante and Cahu, 2001). The knowledge of the digestive tract differentiation concurrent with the changes in food digestion and assimilation processes is necessary for understanding the nutritional physiology of larval fish, and to synchronize feeding practices and rearing protocols with the physiological stage of development (Hoene-Reitan and Kjørsvik, 2004). Such knowledge will allow to overcome one of the major bottlenecks in marine fish hatchery, namely replacement of live preys with compound diet as firstly successfully demonstrated in European sea bass larvae (Cahu et al., 2003).

Marine fish larvae exhibit specific digestive features during the first weeks post-hatching (Krogdahl and Sundby, 1999; Zambonino Infante and Cahu, 2001), and progressively acquire an adult mode of digestion, essential for the further development of the juvenile fish. The larval period represents a transitional period in which the development of larvae is highly influenced by the nature and level of some nutrients incorporated in diets. The ability of larvae to assimilate the required nutrients will depend on the composition of the diet and on their capacity to modulate their digestive enzymes and metabolic processes (Cahu and Zambonino Infante, 2001). Consequently, the study of the ontogeny of digestive enzymes alongside the determination of key indicators of developmental processes may constitute together an appropriate combination of parameters to determine which particular dietary supplies are needed by fish larvae.

This review intends to gather of the data concerning the influence of diets on enzyme expression and development in fish larvae, and their possible applications in terms of recommendations for larvae feed formulation.

\section{Modulation of proteolytic enzymes}

Proteolytic enzymes are mainly located at three different levels of the digestive tract, stomach (pepsin), pancreas (trypsin, chymotrypsin, elastase...) and intestine (membranous and cytosolic enzymes). They have an increasing level of specificity towards the protein/polypeptide chains.

\subsection{Pepsin}

Pepsin is secreted by the gastric glands of the stomach, when present. Indeed, this organ is not differentiated at hatching and progressively develops during larval life (Govoni et al., 1986). Hence, pepsin is expressed later than other digestive enzymes during the larval development as demonstrated in winter flounder and others species (Douglas et al., 1999). The activity levels seem poorly influenced by the dietary proteins. Considering that some fish species are stomachless all along their life, the presence of this enzyme does not seem determinant for protein digestion. The interest of many researchers for this enzyme mainly relates to the fact that its secretion has been associated with the process of morphogenesis, i.e. transition from larvae to juvenile (Govoni et al., 1986).

\subsection{Pancreatic enzymes}

Pancreatic enzymes have been extensively studied and all enzymes examined are generally expressed at first feeding (Cara et al., 2003). Their expression is increasing with age. The secretion of pancreatic enzymes in the intestinal lumen increases during the three first weeks of larval life in temperate species, and this process characterizes the normal maturation of the pancreas (Zambonino Infante and Cahu, 2001). This process is controlled by the level of cholecystokinin in the fish larvae (Kurokawa et al., 2000) which in turn is indirectly and positively regulated by the dietary protein level and chain length (Cahu et al., 2004). Indeed, the trypsin secretion is high in diets incorporating native proteins or a moderate level of protein hydrolysate (around 14\%) while in diets with elevated protein hydrolysate levels (around 46\%) trypsin activity is reduced. Cahu et al. (2004) suggested the existence of a factor controlling cholecystokinin release in fish larvae, sensitive to trypsin hydrolysis and mediating pancreatic enzyme secretion in response to protein intake. Intact proteins, but not hydrolysed proteins, compete for trypsin (trypsin exhibits a higher affinity for intact than hydrolysed proteins) and would prevent the inactivation of this putative factor, which in turn would release cholecystokinin and stimulate pancreatic secretion, as demonstrated in rat (Liddle et al., 1986; Owyang, 1994). The existence of peptides secreted by intestinal epithelial, and probably involved in the control of pancreatic secretion, have been demonstrated in the Japanese flounder (Kurokawa and Suzuki, 2002) and turbot (Reinecke et al., 1997), suggesting that an essential role is played by 
intestinal endocrine system as regulator of the exocrine pancreas in the early larval stage of fish. The possible existence of a cholecystokinin-release factor (Figure 1) likely explains why diets containing high levels of protein hydrolysate do not positively act on the growth and the development of fish larvae, and are not efficient, from a nutritional point of view, in fish juveniles.

Trypsin activity increases with dietary protein level while trypsin transcription remains at a constant level until an advanced developmental stage in sea bass larvae (Cahu et al., 2004). This result suggested that, at the beginning of the fish larvae post-hatching development, it exists a possible stabilisation of trypsin mRNA or a regulation of trypsin expression at the translational level by the dietary protein content, probably through a hormonal mechanism involving cholecystokinin. This last mechanism has been shown in mammals where cholecystokinin mediates the increase in the synthesis of trypsin (and other serine proteases) induced by dietary proteins (Scheele, 1993), and this effect on trypsin synthesis is due to a stimulation of efficiency of mRNA translation. Maximum expression of trypsin was generally obtained with diets containing $50-60 \%$ proteins (Péres et al., 1996). Elevated trypsin synthesis is probably obtained because a supply in $50-60 \%$ dietary protein ensures an optimal binding affinity of trypsin to dietary proteins, preventing cholecystokinin releasing factor hydrolysis. This dietary protein supply coupled with an elevated trypsin synthesis allows at the same time an appropriate cover of amino acid requirement of fish larvae, confirmed by good growth and survival of animals (Péres et al., 1996). The fact that trypsin synthesis would be mainly under hormonal control during young larval stages suggests transient changes in trypsin synthesis (less than 1-2 hours), only occurring in the presence of the hormone as shown in mammals (Scheele, 1993). Considering this physiological aspect of trypsin regulation during early larval stage, a continuous feeding rather than a fractioned one would be more appropriate for fish larvae. Lasting changes (from 2 hours up to 24 hours) in trypsin synthesis could be only considered with the settlement of a transcriptional regulation of trypsin expression, which occurs nearly at the end of the larval period (day 35-42) in European sea bass (Cahu et al., 2004). Furthermore, considering that trypsin transcription is influenced by the protein nature, fish meal being a poor inductor of this transcription (Péres et al., 1998), it would be interesting to test the "performance" of others protein sources for inducing trypsin transcription through partial fish meal replacements in larval feeds.

\subsection{Intestinal enzymes}

Intestinal epithelium is considered to be the structure most likely associated with the terminal digestion of luminal peptides in vertebrates. Intestinal peptides hydrolases are found in two main subcellular locations, the cytosol and the brush border membrane of enterocyte. Cytosolic enzymes are mainly diand tripeptidases located in the enterocyte cytosol, completing protein hydrolysis by reducing peptides to free amino acids. These enzymes are highly expressed in immature enterocyte during the three first weeks of life in larvae of temperate species, while it remains highly expressed in cold water species beyond this initial period (Zambonino Infante and Cahu, 2001). The incorporation of protein hydrolysate in the diet stimulates the activities of these cytosolic peptidases (Cahu and Zambonino Infante, 1995) and consequently facilitates the assimilation of amino acids by the young larvae. It has been shown that intact proteins are 2 to 3 times slower absorbed than hydrolysed proteins, this characteristic probably explains why faecal absorption of intact proteins could be easily observed in fish larvae (Tonheim et al., 2005). Nevertheless, an excessive level of protein hydrolysate in larval feeds leads to negative effects on larval growth and survival (Cahu et al., 1999), probably because high dietary content in protein hydrolysate adversely affects the regulation of trypsin synthesis and secretion, as evoked above. When the maturation of the enterocyte occurs, the activity of these cytosolic enzymes decreases concurrently with the development of several enzymes like alkaline phosphatase and aminopeptidase $\mathrm{N}$ located in the brush border membrane (Cahu and Zambonino Infante, 1995; Ma et al., 2005). These maturational changes occurred earlier when the protein fraction of the diet is constituted by a moderate level (around $20 \%$ of the dry matter) of protein hydrolysate rather than only native protein (Zambonino Infante et al., 1997), and this earlier maturation of enterocytes is always associated with an improvement in larval survival.

Others dietary factors could influence the maturational process of intestinal enzymes. Polyamines are low-molecular-weight, cationic biogenic amines present in every living cell, and therefore can be commonly found in foods and particularly in fish meals (Bardócz et al., 1993). Spermine and spermidine, are known for their positive role on the maturational process of the gastrointestinal tract in birds and mammals (Sousadias and Smith, 1995; Peulen et al., 1998). Similar effects can be obtained in marine fish larvae with diets incorporating $0.33 \%$ spermine or diets containing yeasts that remain alive in the larval gut and secrete spermine (Tovar-Ramirez et al., 2004). The addition of spermine 
(directly or via micro-organisms) could be determinant for larval development, particularly in diets incorporating substitutes of fish meals the latter being naturally rich in polyamines.

\section{Modulation of lipolitic enzymes}

Lipase and phospholipase A2 constitute the main lipolitic enzymes studied until now in fish. These enzymes are secreted by the hepatopancreas in response to the presence in the lumen of their substrates, triglycerides and phospholipids respectively.

Lipases purified or identified from pagrus and winter flounder hepatopancreas exhibit a bile-salt dependency (lijima et al., 1998; Murray et al., 2003), similar to the mammalian bile salt-activated lipase (formerly, carboxylic ester hydrolase). They catalyse the hydrolysis of carboxy-ester bonds, not only triacylglycerols, but also of cholesterol esters or fat-soluble vitamin esters. In mammals, bile saltactivated lipase plays a compensatory role in fat digestion in the suckling animals, where the expression of the pancreatic colipase-dependent lipase is low (Sbarra et al., 1998). Biochemical and molecular assays confirmed that bile salt-activated lipase can be easily detected from mouth opening onwards in fish larvae (Murray et al., 2003; Srivastava et al., 2002). Phospholipase A2 catalyses the hydrolysis of the sn-2 fatty acyl chain of several different phospholipid substrates to yield fatty acids and lysophospholipids (Arni and Ward, 1996); Phospholipase A2 is the major enzyme for digesting dietary and biliary phospholipids and, probably due to the lack of sensitive and easy-to-use techniques, this enzyme has only be detected some days after mouth opening (Zambonino Infante and Cahu, 2001). The expression of these lipase and phospholipase A2 is mainly regulated at the transcriptional level, even though post-transcriptional regulations have been described in some cases (Morais et al., 2004).

The response of pancreatic lipase to dietary triglyceride level was not linear in sea bass larvae fed diets containing triglycerides ranging from $13 \%$ to $23 \%$ (Figure $2 \mathrm{~A}$ ), showing a threshold, around $20 \%$ triglycerides, at which the maximum lipase activity and messenger level were reached (Cahu et al., 2003). On the contrary, the response of phospholipase $A 2$ to dietary phospholipid level (ranging from 3 to $12 \%$ ) was gradual (Figure 2B) with a $800 \%$ and $70 \%$ increase in activity and messenger level respectively. These differences between lipase and phospholipase A2 expression strongly suggest that fish larvae are better prepared to digest phospholipids rather than triglycerides.

Several authors have shown that lipid digestion and absorption processes in fish mainly occurred in the anterior region of the intestine (Diaz et al., 1997; Olsen et al., 1999). Nevertheless, Gisbert et al. (2005) have revealed that different patterns of lipid absorption and accumulation can be observed in the intestinal mucosa in European sea bass larvae depending on the level and class of the lipid used in the diet. Indeed, important intracellular and intercellular accumulation of lipids was noted in the anterior intestine of fish fed diets containing high levels (58\%) of triglycerides in the lipid fraction, while no such accumulation was evidenced when larvae were fed with moderate levels (around 30\%) of triglycerides in the lipid fraction. Diets incorporating inadequate sources of lipids or high levels of triglycerides always induce an accumulation of lipid droplets in the enterocytes of the anterior intestine (Caballero et al., 2003) even though this accumulation has not been described as being the cause of any pathological damage. Moreover, deposition of large lipid vacuoles were also observed in the postvalvular intestinal mucosa of larvae fed diets incorporating high levels of phospholipids (more than $60 \%$ ), revealing that phospholipids were preferentially absorbed in the postvalvular intestine (Gisbert et al., 2005).

The accumulation of triglycerides in the anterior intestine probably reflects a limited capacity for leaving the enterocytes, indicating a poor capacity for assembling triglycerides with apolipoprotein B (necessary for their secretion and their transfer into the circulation). This hypothesis is strengthened by recent data concerning the microsomal triglyceride transfer protein (MTP) of teleost fish. MTP is an intracellular protein required for the assembly and secretion of triglycerides-rich lipoproteins, its expression being restricted to the anterior intestine (Marza et al., 2005). For triglycerides, MTP exhibited a transfer specific activity 4 times lower in the anterior intestine of zebra fish larvae than that of young mice (Marza, 2005), while no difference were noted for cholesterol esters. Consequently, the presence of large lipid droplets in fish enterocytes might be explained by the high efficiency and capacity of the anterior intestine for triglyceride absorption, which can exceed the capacity of enterocytes to secrete triglycerides-rich lipoproteins, particularly when feeding larvae with high dietary triglyceride levels. It would be interesting to verify whether another protein Sar1b can be detected and is functional in fish larvae. Sar1b is involved in the secretion of chylomicrons by enterocytes and a dysfunction of the gene Sara2 coding for this protein induces intestinal steatosis in mammals (Jones et al., 2003). 
The previous considerations concerning lipid digestion and absorption strongly suggest that the lipid fraction of diets intended for marine fish larvae should incorporate a significant fraction of phospholipids instead of triglycerides. Actually, the incorporation of $12 \%$ phospholipids in diets resulted in 18 times and 3 times increase in growth and survival respectively, compared to a isolipidic diet but containing only $3 \%$ phospholipids (Cahu et al., 2003).

\section{Modulation of some metabolic pathways controlling development}

Studies have shown that there is a close relationship between larval nutrition at first feeding and development, this relationship being easily observed in the case of skeletal abnormalities (Zambonino Infante et al. 1997; Suzuki et al. 2000). Some developmental genes, and particularly those involved in body patterning, can be regulated by the nature and molecular form of the nutrients (Suzuki et al., 2000; Balmer and Blomhoff, 2002; Haga et al. 2003). Indeed, ongoing research has shown that some nutrients interact with specific nuclear receptors, Retinoic Acid Receptors (RAR) and Retinoid X Receptors (RXR) with vitamin A (Suzuki et al., 2000; Villeneuve et al., 2005a), Peroxisome Proliferator-Activated Receptors (PPAR) with polyunsaturated fatty acids (Kliewer et al., 1997; Bonilla, et al., 2000; Villeneuve et al., 2005b) and Vitamin D Receptor (VDR) with Vitamin D (Suzuki et al., 2000; Thompson et al., 2001). These receptors function by forming obligate heterodimers with RXR, involved in nearly all processes associated with development, emphasizing the pivotal role in the signalling network played by the retinoid pathway. The expression of these receptors is modulated by the dietary level of their specific ligands, and these modulations strongly impact other signalling pathways (Figure 3 ) determining the morphological and functional development of marine fish larvae (Villeneuve, 2005). Villeneuve et al. (2005a) have shown that high dietary levels of vitamin A affected pancreas and intestine maturation of European sea bass larvae, and found that the optimal dietary retinyl acetate level was close to $31 \mathrm{mg} / \mathrm{kg}$ DM. RAR receptors are mainly expressed in the head area of the young larvae (Figure 4A). Consequently, inappropriate levels of dietary vitamin A during the early larval period mainly resulted in the alteration of head organization characterized by the abnormal development of the splanchnocranium and neurocranium (Figure 4C), even though some scoliotic fish could be observed (Haga et al., 2003; Villeneuve et al;, 2005a). A positive linear correlation between dietary vitamin A levels (from $10 \mathrm{mg}$ to $1000 \mathrm{mg} / \mathrm{kg}$ of dry matter) and malformation rates was observed and the appearance of malformations was associated with a huge (80 times) up-regulation of RARgamma (Figure 4B) expression during the two first weeks post-hatching (Villeneuve et al., 2005a). High dietary levels of polyunsaturated fatty acids mainly affected column morphogenesis in European sea bass larvae, when supplied as triglycerides or phospholipids respectively (Villeneuve et al., 2005b). In the case of triglycerides, this effect seemed to be mediated by an up-regulation of $\mathrm{RXR} \alpha$ expression (likely induced by an up-regulation of PPAR) when the expression of this gene decreases during normal larval development. Based on these observations, Villeneuve et al. (2005b) indicated that the most appropriate dietary supply in DHA and EPA for European sea bass larvae should be a DHA/EPA ratio of 2.2 with a level of (EPA plus DHA) of $2.3 \%$, the more efficient mode of supply being phospholipids.

Nevertheless, uncharacterised cross-talks between these different signalling pathways make a global approach necessary in order to better define nutritional requirements of the developing fish.

\section{Conclusion}

The data reported in this article show that nutrition can affect many mechanisms controlling development fish larvae. Although this review cannot be considered comprehensive with respect to all physiological functions related to the gastrointestinal tract, it clearly demonstrates that fish larvae should not be considered as primitive organisms but represent a transitional period in which both ontogeny and growth cause substantial changes in structure, physiology, size and body shape. The development process of fish larvae can be affected by several genetic and environmental factors, in particular the availability and composition of feeds during early stages of larval life. Therefore, experiments only examining the effects of many combinations of nutrients on larval growth and survival are not sufficient for determining the nutritional requirements of developing marine fish larvae. It is also necessary to consider several physiological indicators to take into account the developmental aspect. This point brings to light the necessity to have a global knowledge of the physiology and developmental mechanisms of fish larvae, and to identify the possible cross-talks between metabolic processes.

This knowledge will allow to identifying potential indicator markers for use in quality control of fish larvae rearings, formulating new recommendations for nutrient requirements resulting in a better 
nutritional control of the quality of fish larvae produced in hatcheries. This better quality will indubitably improve and increase public acceptance of the fish produced by aquaculture. 


\section{References}

Arni, R.K., Ward, R.J., 1996. Phospholipase A2- A structural review. Toxicon. 34, 827-841.

Balmer, J.E., Blomhoff, R., 2002. Gene expression regulation by retinoic acid. J Lipid Res 43, 17731808.

Bardócz, S., Grant, G., Brown, D.S., Ralph, A., Pusztai, A., 1993. Polyamines in food-implications for growth and health. J. Nutr. Biochem. 4, 66-71.

Bonilla, S., Redonnet, A., Noël-Suberville, C., Pallet, V., Garcin, H., Higueret, P., 2000. High-fat diets affect the expression of nuclear retinoic acid receptor in rat liver. Br. J. Nutr. 83, 665-671.

Caballero, M.J., Izquierdo, M.S., Kjørsvik, E., Montero, D., Socorro, J., Fernandez, A.J., Rosenlund, G., 2003. Morphological aspects of intestinal cells from gilthead seabream (Sparus aurata) fed diets containing different lipid sources. Aquaculture 225, 325-340.

Cahu, C.L., Zambonino Infante, J.L., 1995. Effect of the molecular form of dietary nitrogen supply in sea bass larvae: response of pancreatic and intestinal peptidases. Fish Physiol. Biochem. 14, 209214.

Cahu, C.L., Zambonino Infante, J.L., 2001. Substitution of live food by formulated diets in marine fish larvae. Aquaculture 200, 161-180.

Cahu, C.L., Rønnestad, I., Grangier, V., Zambonino Infante, J.L., 2004. Expression and activities of pancreatic enzymes in developing sea bass larvae (Dicentrarchus labrax) in relation to intact and hydrolysed dietary protein; involvement of cholecystokinin. Aquaculture 238, 295-308.

Cahu, C.L., Zambonino Infante, J.L., Barbosa V., 2003. Effect of dietary phospholipid level and phospholipid: neutral lipid value on the development of sea bass (Dicentrarchus labrax) larvae fed a compound diet. Br. J. Nutr. 90, 21-28.

Cahu, C.L., Zambonino Infante, J.L., Quazuguel, P., Le Gall, M.M., 1999. Protein hydrolysate vs fish meal in compound diets for 10-day-old sea bass Dicentrarchus labrax larvae. Aquaculture 171, 109119.

Cara, J.B., Moyano, F.J., Cardenas, S., Fernandez-Diaz, C., Yufera, M., 2003. Assessment of digestive enzyme activities during larval development of white bream. J. Fish Biol. 63, 48-58.

Diaz, J.P., Guyot, E., Vigier, S., Connes, R., 1997. First events in lipid absorption during postembryonic development of the anterior intestine in gilt-head sea bream. J. Fish Biol. 51, 180-192.

Douglas, S., Gawlicka, A., Mandla, S., Gallant, J.W., 1999. Ontogeny of the stomach in the winter flounder: characterization and expression of the pepsinogen and proton pump genes and determination of pepsin activity. J. Fish Biol. 55, 897-915.

Gisbert, E., Villeneuve, L., Zambonino Infante, J.L., Quazuguel, P., Cahu, C.L., 2005. Dietary phospholipids are more efficient than neutral lipids for long chain polyunsaturated fatty acid supply in European sea bass Dicentrarchus labrax larval development. Lipids 40, 609-618.

Govoni, J.J., Boehlert, G.W., Watanabe, Y., 1986. The physiology of the digestion in fish. Env. Biol. Fish. 16, 59-77.

Haga, Y., Suzuki, T., Kagechika, H., Takeuchi, T., 2003. A retinoic acid receptor-selective agonist causes jaw deformity in the Japanese flounder, Paralichthys olivaceus. Aquaculture 221, 381-392.

Hoene-Reitan, K., Kjørsvik, E., 2004. Functional development of the liver and exocrine pancreas in teleost fish. In: Govoni, J.J. (ed), The development of form and function in fishes and the question of larval adaptation. American Fisheries Society, Symposium 40, Bethesda, Maryland, pp. 9-36. 
lijima, N., Tanaka, S., Ota, Y., 1998. Purification and characterization of bile salt-activated lipase from the hepatopancreas of red sea bream, Pagrus major. Fish Physiol. Biochem. 18, 59-69.

Jones, B., Jones, E.L., Bonney, S.A., Patel, H.N., Mensenkamp, A.R., Eichenbaum-Voline, S., Rudling, M., Myrdal, U., Annesi, G., Naik, S., Meadows, N., Quattrone, A., Islam, S.A., Naoumova, R.P., Angelin, B., Infante, R., Levy, E., Roy, C.C., Freemont, P.S., Scott, J., Shoulders, C.C., 2003. Mutations in a Sar1 GTPase of COPII vesicles are associated with lipid absorption disorders. Nat. Genet. 34, 29-31.

Kliewer, S. A., Sundseth, S. S., Jones, S. A., Brown, P.J., Wisely, B., Koble, C.S., Devchand, P., Wahli, W., Willson, T.M., Lenhard, J.M., Lehmann, J.M., 1997. Fatty acids and eicosanoids regulate gene expression through direct interactions with peroxisome proliferator-activated receptors $\alpha$ and $\gamma$. Proc. Natl. Acad. Sci. 94, 4318-4323.

Krogdahl, A., Sundby, A., 1999. Characteristics of pancreatic function in fish. In: Pierzynowski S.G. and Zabielski R., (eds), Biology of the pancreas in growing animals. Elsevier Science, Amsterdam, pp. 437-458.

Kurokawa, T., Suzuki, T., Andoh, T., 2000. Development of cholecystokinin and pancreatic polypeptide endocrine systems during the larval stage of Japanese flounder, Paralichthys olivaceus. Gen. Comp. Endocr. 120, 8-16.

Kurokawa, T., Suzuki, T., 2002. Development of neuropeptide Y-related peptides in the digestive organs during the larval stage of Japanese flounder, Paralichthys olivaceus. Gen. Comp. Endocr. 126, 30-38.

Liddle, R.A., Green, G.M., Conrad, C.K., Williams, J.A., 1986. Proteins but not amino acids, carbohydrates, or fats stimulate cholecystokinin secretion in the rat. Am. J. Physiol. 251, G243-G248.

Ma, H., Cahu, C., Zambonino, J., Yu, H., Duan, Q., Le Gall, M.M, Mai, K., 2005. Activities of selected digestive enzymes during larval development of large yellow croaker (Pseudosciaena crocea). Aquaculture 245, 239-248.

Marza, E., 2005. Structure, implication évolutive et régulation ontogénique et nutritionnelle de l'expression des gènes codant pour les apoliproteins $B$ et la grand sous-unité de la microsomal triglyceride transfer protein du poisson zèbre (Danio rerio). PhD thesis, January 25th 2005, University of Bordeaux 1, France, 207p.

Marza, E., Barthe, C., André, M., Villeneuve, L., Hélou, C., Babin, P.J., 2005. Developmental expression and nutritional regulation of a zebrafish gene homologous to mammalian microsomal triglyceride transfer protein large subunit. Dev. Dynam. 232, 506-518.

Morais, S., Cahu, C., Zambonino Infante, J.L., Robin, J., Rønnestad, I., Dinis, M.T., Coneição, L.E.C., 2004. Dietary triacylglycerol source and level affects performance and lipase expression in larval seabass (Dicentrarchus labrax). Lipids 39, 449-458.

Murray, H.M., Gallant, J.W., Perez-Casanova, Johnson, S.C., Douglas S.E., 2003. Ontogeny of lipase expression in winter flounder. J. Fish Biol. 62, 816-833.

Olsen, R.E., Myklebust, R., Kaino, T., Ringo, E., 1999. Lipid digestibility and ultrastruyctural changes in the enterocytes of Artic char (Salvelinus alpimus L.) fed linseed oil and soybean lecithin. Fish Physiol. Biochem. 21, 35-44.

Owyang, C., 1994. Negative feedback control of exocrine pancreatic secretion: role of cholecystokinin and cholinergic pathway. J. Nutr. 124, 1321S-1326S.

Péres, A., Cahu, C.L., Zambonino Infante, J.L., Le Gall, M.M., Quazuguel, P., 1996. Amylase and trypsin responses to intake of dietary carbohydrate and protein depend on the developmental stage in sea bass (Dicentrarchus labrax) larvae. Fish Physiol. Biochem. 15, 237-242 
Péres, A., Zambonino Infante, J.L., Cahu, C.L., 1998. Dietary regulation of activities and mRNA levels of trypsin and amylase in sea bass (Dicentrarchus labrax) larvae. Fish. Physiol. Biochem. 19, 145-152

Peulen, O., Pirlet, C., Klimek, M., Goffinet, G., Dandrifosse, G., 1998. Comparison between the natural postnatal maturation and the spemine-induced maturation of the rat intestine. Arch. Physiol. Biochem. $106,46-55$.

Reinecke, M., Müller, C., Segner, H., 1997. An immunohistochemical analysis of the ontogeny, distribution and coexistence of 12 regulatory peptides and serotonin in endocrine cells and nerve fibers of the digestive tract in the turbot, Scophthalmus maximus (Teleostei). Anat. Embryol. 195, 87101.

Sbarra, V., Bruneau, N., Mas, E., Hamosh, M., Lombardo, D., Hamosh, P., 1998. Molecular cloning of the bile salt-dependent lipase of ferret lactating mammary gland: an overview of functional residues. Biochem. Biophys. Acta 1393, 80-89.

Sheele, G.A., 1993. Regulation of pancreatic gene expression in response to hormones and nutritional substrates. In: Go, V.L.W., Gardner, J.D., Brooks, F.P., Lebenthal, E.P., Di Magno, E.P. and Sheele, G.A., (eds), The Pancreas: Biology, Pathobiology, and Disease. Raven Press, New York, pp.103-120.

Sousadias, M.G., Simth, T.K., 1995. Toxicity and growth-promoting potential of spermine when fed to chicks. J. Anim. Sci. 73, 2375-2381.

Srivastava, A.S., Kurokawa, T., Suzuki, T., 2002. mRNA expression of pancreatic enzyme precursors and estimation of protein digestibility in first feeding larvae of the Japanese flounder, Paralichthys olivaceus. Comp. Biochem. Physiol. 132A, 629-635.

Suzuki, T., Srivastava, A.S., Kurokawa, T., 2000. Experimental induction of jaw, gill and pectoral fin malformations in Japanese flounder, Paralichthys olivaceus, larvae. Aquaculture 185, 175-187.

Suzuki, T., Suzuki, N.,Srivastana, A.S., Kurokawa, T., 2000. Identification of cDNAs encoding two subtypes of vitamin D receptor in flounder, Paralichthys olivaceus. Biochem. Biophys. Res. Com. 270, 40-45.

Thompson, P.D., Remus, L.S., Hsieh, J.C., Jurutka, P.W., Whitfield, G.K., Galligan, M.A., Encinas Dominguez, C., Haussler, C.A., Haussler, M.R., 2001. Distinct retinoid receptor activation function-2 residues mediate transactivation in homodimeric and vitamin $\mathrm{D}$ receptor heterodimeric contexts. $\mathrm{J}$. Mol. End. 27, 211-227.

Tonheim, S.K., Espe, M., Hamre, K., Rønnestad, I., 2005. Pre-hydrolysis improves utilisation of dietary protein in the larval teleost Atlantic halibut (Hippoglossus hippoglossus). J. Exp. Mar. Biol. 321, 19-34.

Tovar-Ramirez, D., Zambonino Infante, J.L., Cahu, C.L., Gatesoupe, F.J., Vázquez-Juárez, R., 2004. Dietary incorporation level of live yeast influences European sea bass (Dicentrarchus labrax) larval development. Aquaculture 234, 415-427.

Villeneuve, L., 2005. Influence nutritionnelle de la vitamine A et de la nature des lipides sur la morphogenèse de la larve de bar (Dicentrarchus labrax) : implication de la voie des rétinoïdes. $\mathrm{PhD}$ thesis, February 9th 2005, University of Rennes 1, France, 243p.

Villeneuve, L., Gisbert, E., Le Delliou, H., Cahu, C.L., Zambonino Infante, J.L., 2005a. Dietary levels of all-trans retinol affect retinoid nuclear receptor expression and skeletal development in European sea bass larvae. Br. J. Nutr. 93, 1-12.

Villeneuve, L., Gisbert, E., Zambonino Infante, J.L., Quazuguel, P., Cahu, C.L., 2005b. Effect of nature of dietary lipids on European sea bass morphogenesis: implication of retinoid receptors. Br. J. Nutr. 94: 877-884. 
Zambonino Infante, J.L., Cahu, C.L., Péres, A., 1997. Partial substitution of native fish meal protein by di- and tripeptides in diet improves sea bass (Dicentrarchus labrax) larvae development. J. Nutr. 127, 608-614.

Zambonino Infante, J.L., Cahu, C.L., 2001. Ontogeny of the gastrointestinal tract of marine fish larvae. Comp Biochem. Physiol. Part C, 130, 477-487. 


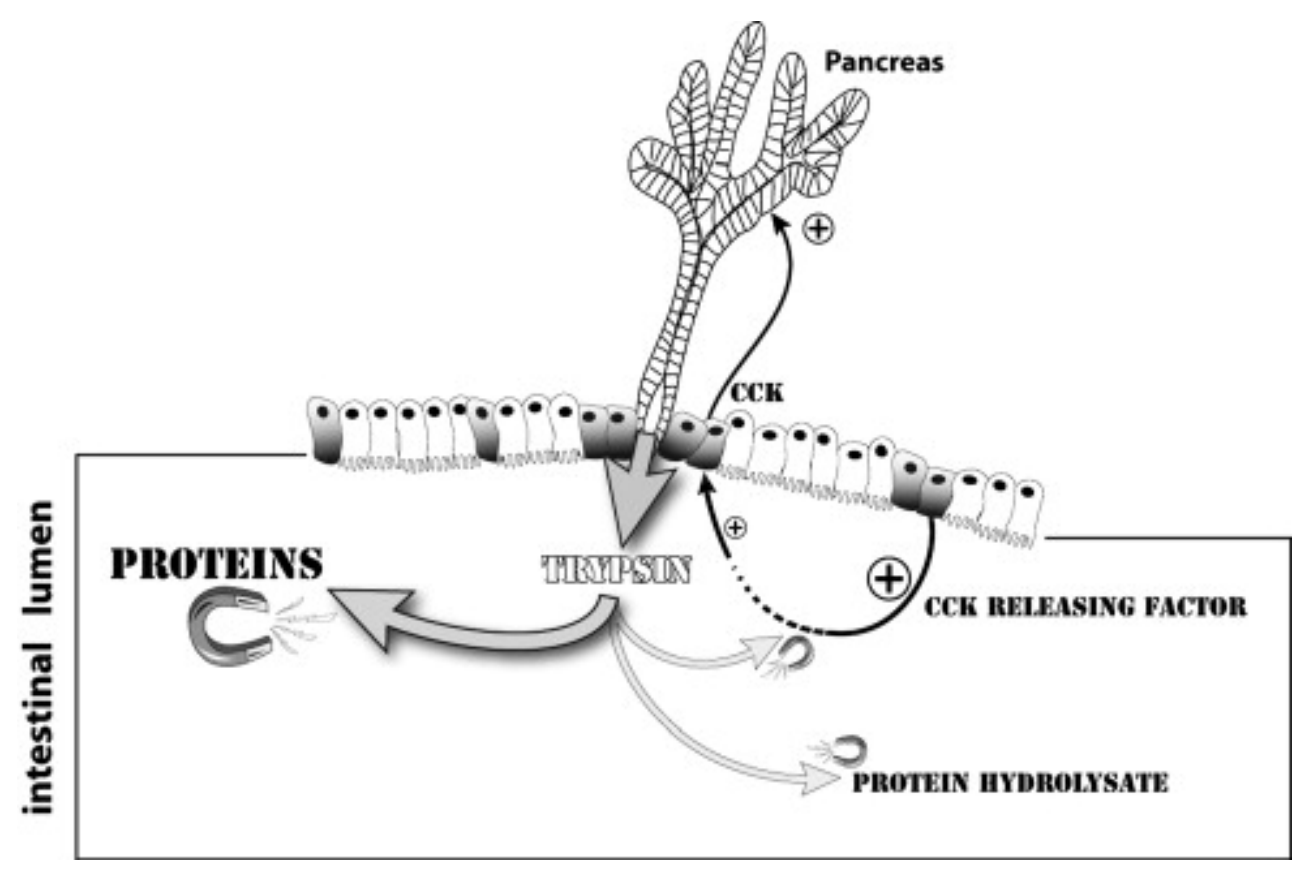

Figure 1. Possible existence of a cholecystokinin-releasing factor, trypsin sensitive, regulating cholecystokinin secretion and therefore trypsin secretion in European sea bass larvae fed native proteins or hydrolysed one. 

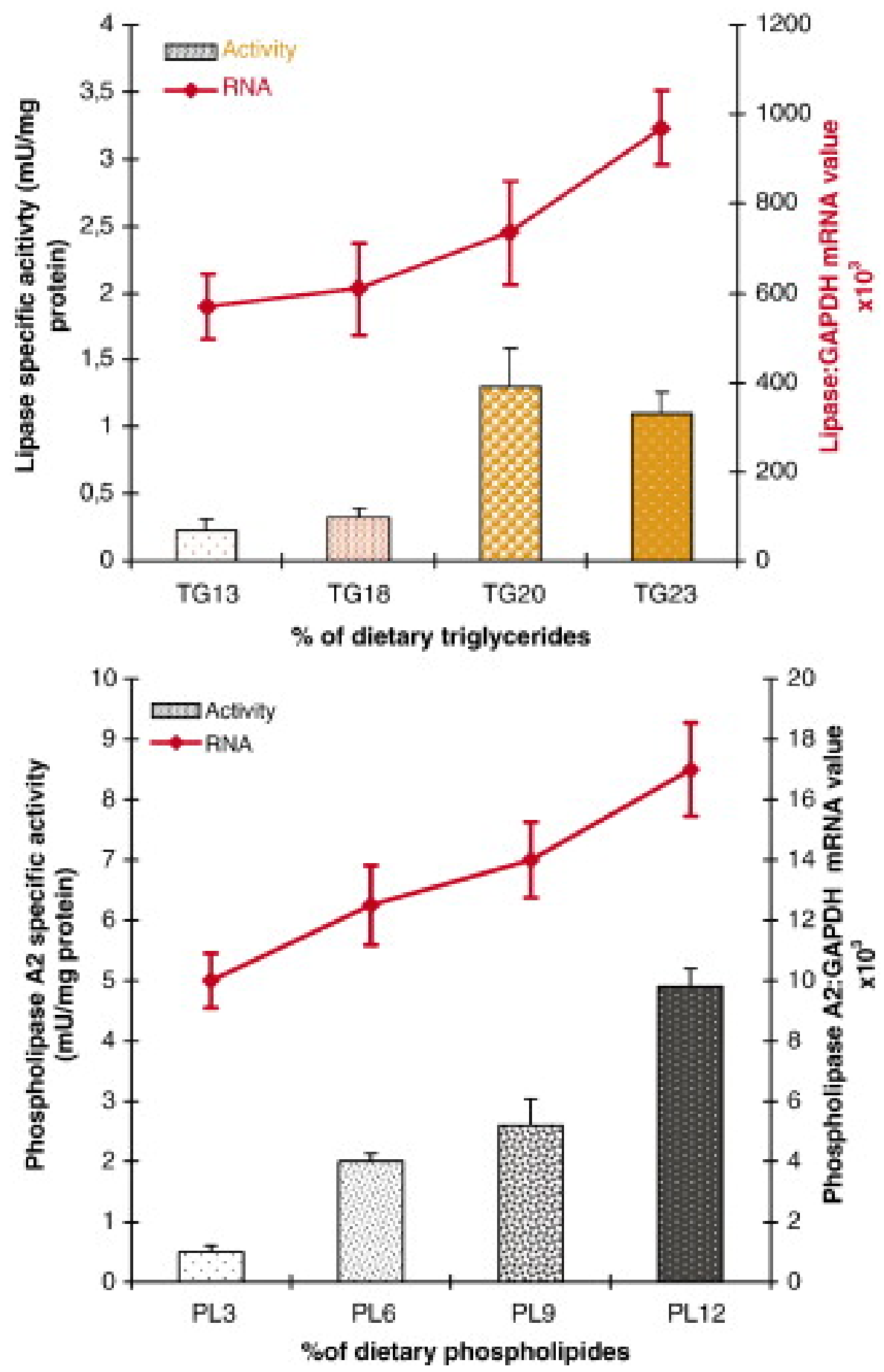

Figure 2. Activities and value of (A) lipase mRNA / glyceraldehyde-3-phosphate deshydrogenase (GAPDH) mRNA and (B) phospholipase A2 mRNA / glyceraldehyde-3-phosphate deshydrogenase mRNA in 40-day-old European sea bass larvae fed diets incorporating different levels of triglycerides (TG) and phospholipids 5PL), respectively (from Cahu et al., 2003). 


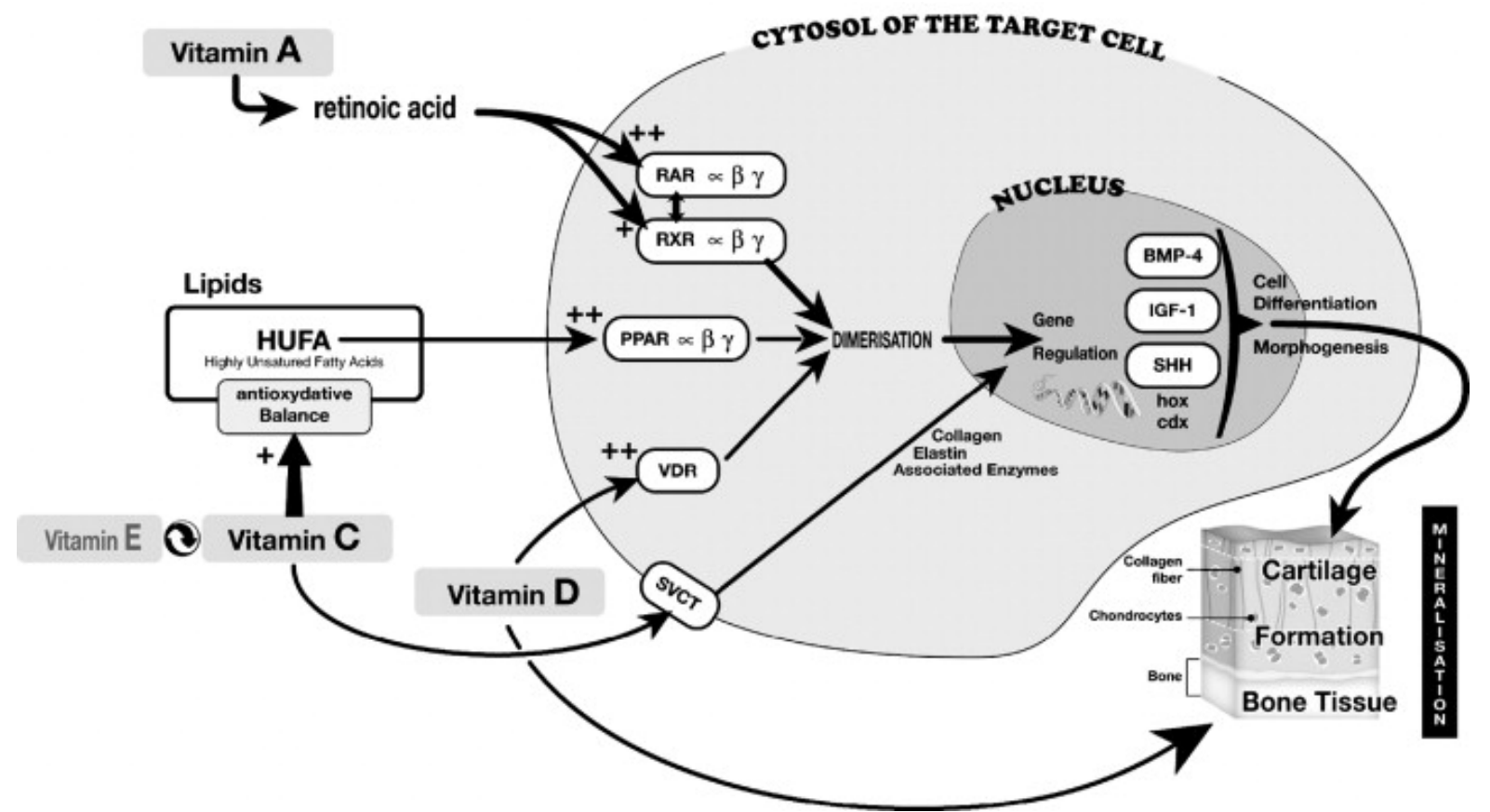

Figure 3. Possible involvement of some metabolic pathways mediating the influence of some dietary nutrients on the development and morphogenesis of marine fish larvae. RAR: Retinoic Acid Receptor, RXR: Retinoid X Receptor, PPAR: Peroxisome Proliferator Activated Receptor, VDR: Vitamin D Receptor, SVCT: Vitamin C transporter system, BMP: gene coding for Bone Morphogenetic Protein, IGF: gene coding for Insulin-like Growth Factor; SHH: sonic hedgehog gene, hox: hox genes, cdx: caudal-related homeobox genes. 

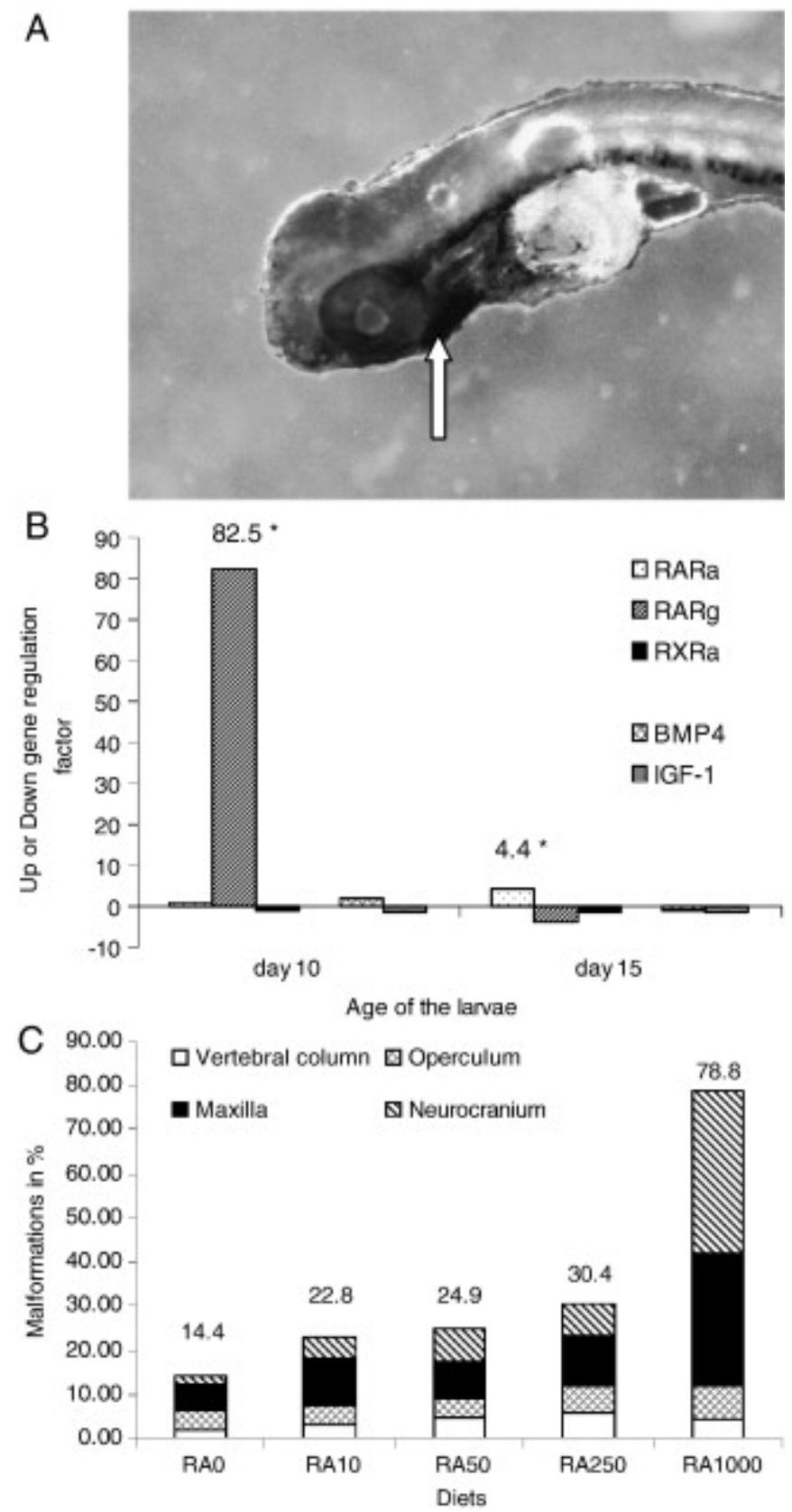

Figure 4.

(A) Localization of RARa messenger: in situ Hybridization with RAR a antisense in European sea bass larvae at $5 \mathrm{dph}$. The white arrow indicates RARa expression in the lower jaw region. (from Villeneuve et al. 2004).

(B) Effect of diet containing 1000 mg/kg of retinyl acetate (Vitamin A) in European sea bass larvae. Relative gene expression ratios of RARa, RARy, RXRa, BMP-4 and IGF-I at 10 and $15 \mathrm{dph}$. The numbers and asterisks $(P<0.05)$ indicate the relative gene expression ratio and significant differences within a same developmental stage compared to the control group fed a moderate level of retinyl acetate $(50 \mathrm{mg} / \mathrm{kg}$ ) at the same dates. (from Villeneuve et al., 2005)

(C) Incidence of skeletal malformations in European sea bass larvae fed diets containing different doses of all-trans retinol, ranging from 0 to $1000 \mathrm{mg} / \mathrm{kg}$ of dry matter. (from Villeneuve et al., 2005) 